\title{
STRATEGI PEMBERDAYAAN MASYARAKAT DALAM PENGELOLAAN HUTAN MANGROVE
}

\author{
Siti Mahmudah*, Siti Malikhatun Badriyah, Bambang Eko Turisno, Amiek Soemarmi \\ Fakultas Hukum Universitas Diponegoro \\ J1. Prof. Soedarto, S.H, Tembalang, Semarang \\ sitimahmudah.fhundip@gmail.com
}

\begin{abstract}
The use of mangrove forests is a people's right guaranteed by law, which requires community empowerment. This purpose to identify community empowerment strategies in mangrove management with normative juridical writing method, descriptive writing specification analysis using secondary data, qualitative analysis. Community empowerment strategies in managing mangrove forests through the persuasive, educational and facilitative methods found in the partnership under the No. 20 of 2008 Micro, Small and Medium Enterprises Act, implemented with PP No. 17 of 2013, which can be implemented in a variety of patterns partnership. The partnership patterns can be used in empowering coastal communities managing mangrove forests, the choice of partnership patterns to be used is adjusted to the needs of the local community.
\end{abstract}

Keywords: Community Development; Society; Mangrove

\begin{abstract}
Abstrak
Pemanfaatan hutan mangrove merupakan hak masyarakat yang dijamin dalam Undang-Undang, yang memerlukan pemberdayaan masyarakat. Pembahasan ini ditujukan untuk mengetahui strategi pemberdayaan masyarakat dalam pengelolaan hutan mangrove dengan metode penulisan yuridis normatif, spesifikasi penulisan deskriptif analitis yang menggunakan data sekunder, analisis kualitatif. Strategi pemberdayaan masyarakat dalam pengelolaan hutan mangrove melalui metode persuasif, edukatif, dan fasilitatif yang terdapat dalam kemitraan usaha dalam Undang-Undang Nomor 20 Tahun 2008 Tentang Usaha Mikro, Kecil, dan Menengah, yang dilaksanakan dengan PP No 17 Tahun 2013 dimana dapat dilaksanakan dengan berbagai pola kemitraan. Pola-pola kemitraan tersebut dapat digunakan dalam pemberdayaan masyarakat pesisir pengelola hutan mangrove, pemilihan pola kemitraan yang akan digunakan disesuaikan dengan kebutuhan masyarakat setempat.
\end{abstract}

Kata Kunci: Pemberdayaan Masyarakat; Pengelolaan; Mangrove

\section{A. Pendahuluan}

Keberadaan kawasan pesisir dan lautan memiliki fungsi multi dimensional antara lain sebagai media diplomasi dan hubungan social antar bangsa, media transportasi dan komunikasi, sumber kehidupan bagi kesejahteraan masyarakat, pendapatan dan devisa Negara serta media pertahanan dan keamanan (Soedarsono, 2004). Pengelolaan kawasan pesisir dan laut bagi bangsa Indonesia merupakan sesuatu hal yang sangat penting dan sangat berarti, karena dengan dimanfaatkannya berbagai potensi sumber daya alam di kawasan pesisir laut secara optimal dapat meningkatkan pendapatan dan kesejahteraan masyarakatnya (Soedarsono, 2004).

Pengelolaan kawasan pesisir dan laut harus dilakukan dengan pola berkelanjutan, 
baik dalam dimensi ekonomi, sosial, maupun ekologi yang salain berkaitan. Dalam dimensi ekonomi harus dapat mewujudkan efisiensi, sedangkan dalam dimensi sosial harus tampak adanya pendistribusian maupun pemanfaatan secara adil untuk mewujudkan tidak meluasnya pemiskinan masyarakat di kawasan pantai tidak semakin meluas. Pengeloaan dari dimensi ekologi harus dipusatkan pada upaya untuk mencegah terjadinya berbagai risiko yang dapat mengganggu fungsi layanan ekologi, khususnya yang dapat mengancam keberlanjutan hidup aneka ragam hayati yang ada di kawasan tersebut (Soedarsono, 2004).

Hutan mangrove adalah hutan yang tumbuh di muara sungai, daerah pasang surut atau tepi laut (Edi Mulyadi, Nur Fitriani, 2010). Mangrove merupakan sekelompok tumbuhan yang hidup di daerah pesisir, yang merupakan sekelompok tumbuhan yang terdiri berbagai jenis dan suku, tetapi mempunyai persamaan dalam hal adaptasi morfologi dan fisiologi terhadap habitat yang dipengaruhi oleh pasang surut (Ekosistem peralihan antara daratan dengan laut ataupun dengan perairan sekitar muara sungai). Mengrove merupakan produk Sumber Daya Alam Hutan dan Ekowisata (SDAHE) yang berupa manfaat langsung (tangible) dan/atau manfaat tidak langsung (intangible) meliputi jasa wisata alam/rekreasi, jasa perlindungan tata air/hidrogen, keindahan, keunikan, serta penyerahan dan penyimpanan karbon (Bonorowo, 2015).

Di Indonesia, hutan Mangrove tumbuh dan tersebar di seluruh nusantara mulai dari Pulau Sumatra sampai dengan Irian. Ditemukan ada sekitar 202 jenis mangrove yang hidup pada hutan mangrove, yang meliputi 89 jenis pohon, 5 jenis palm, 19 jenis pemanjat,44 jenis terna, 44 jenis epifit, 1 jenis paku- pakuan (Pramudi, 2001).

Pemanfaatan ekosistem mangrove telah lama dilakukan oleh masyarakat, Mangrove berperan sebagai filter untuk mengurangi efek yang merugikan dan perubahan lingkungan utama dan sebagai sumber makanan bagi biota laut (pantai) dan biota baru, ekosistem ini juga berfungsi dalam mengolah limbah melalui penyerapan kelebihan nitrat dan phospat sehingga dapat mencegah pencemaran dan kontaminasi di perairan sekitarnya (Nurul Huda, 2008). Pemanfaatan ekosistem mangrove dilakukan oleh masyarakat antara lain dengan mengeksport udang, kepiting yang mempunyai nilai tinggi, sehingga mampu meningkatkan kesejahteraan masyarakat sebagaimana yang banyak dilakukan diberbagai daerah di Indonesia, termasuk provinsi Sulawesi Selatan (Umiha \& Asbar, 2006).

Di kota Semarang ada sekelompok ibuibu rumah tangga yang memanfaatkan buah dari pohon bakau menjadi bahan dasar aneka panganan, sebagaimana yang dilakukan oleh Ibu-ibu warga RT. 01 RW. I Kelurahan Mangunharjo Kecamatan Tugu, Kota Semarang. Kegiatan mereka mampu menghasilkan keuntungan, mengingat bahwa mangrove yang dikelola dengan baik dapat meningkatkan perekonomian masyarakat wilayah pesisir. Di sisi lain, masyarakat mempunyai hak untuk mengelola mangrove yang dijamin oleh UU. Oleh karenanya diperlukan adanya pemberdayaan masyarakat yang merupakan upaya untuk meningkatkan martabat lapisan masyarakat yang dalam kondisi sekarang kurang mampu melepaskan diri dari perangkap kemiskinan dan keterbelakangan.

Berkaitan dengan pemberdayaan masyarakat dalam pengelolaan mangrove, sebelumnya telah diteliti oleh Bambang Eko Turisno, R.Suharto, dan Ery Agus Priyono di kota Pekalongan, dalam penelitian yang berjudul "Peran Serta Masyarakat Dan Kewenangan Pemerintah Dalam Konservasi Mangrove Sebagai Upaya Mencegah Rob dan Banjir Serta Sebagai Tempat Wisata", dalam upaya untuk pencegahan banjir dan rob, tempat wisata yang berupa penanaman pohon mangrove yang digunakan sebagai rehabilitasi pantai dengan dilakukan langsung penanaman di tanah atau dengan 
teknik bronjong serta melibatkan masyarakat setempat.

Pemberdayaan masyarakat khususnya pengusaha kecil termasuk pemberdayaan mangrove dalam rangka peningkatan perekonomian perlu adanya suatu kerjasama yang saling menguntungkan, yang dikenal dengan kemitraan usaha. Kemitraan antara usaha besar dengan usaha kecil dapat membantu usaha kecil untuk mengatasi kelemahannya antara lain melalui modal, pemasaran dan teknologi. Kelemahankelemahan ini juga terjadi pada usaha-usaha kecil dalam pengelolaan mangrove.

Penelitian tentang kemitraan antara usaha kecil dan usaha besar pernah dilakukan oleh Siti Mahmudah, dalam Tesisnya yang berjudul "Tinjauan Yuridis Terhadap Kerjasama Pola Subkontrak Pada Industri Kecil (Studi Kasus Pada Industri Logam)". Dalam penelitian tersebut kerjasama antara usaha kecil dan menengah dilakukan dalam bentuk sub kontrak. Kerjasama tersebut dituangkan dalam bentuk perjanjian yang isinya antara lain adanya bantuan oleh pengusaha besar yang meliputi modal dan alih teknologi (Siti Mahmudah, 2008).

Terkait dengan hal tersebut di atas, penulis ini akan mengkaji bagaimana strategi pemberdayaan masyarakat dalam pemanfaatan hutan mengvore sebagai upaya peningkatan ekonomi dan konservasi hutan mengvore yang berkelanjutan. Metode penulisan yang digunakan adalah yuridis normatif, melalui studi pustaka yang berupa data sekunder, meliputi bahan hokum primer, sekunder, maupun tersier.

\section{B. Pembahasan}

\section{Strategi Pemberdayaan Masyarakat dalam Pengelolaan Hutan Mengvore}

Pengelolaan wilayah pesisir khususnya dalam pengelolaan mangrove secara umum terdapat tiga komponen pokok yang harus diperhatikan dalam upaya pengelolaan dan pemanfaatan ekosistem mengrove khususnya dan sumber daya alam pesisir dan laut umumnya diantaranya aktivitas sosial (social processes), ekonomi (economic processes) dan sumber daya alam itu sendiri (natural processes). Ketiga komponen tersebut saling terkait dan saling mempengaruhi satu sama lain. Aspek sosialekonomi, budaya dan estetik manusia membutuhkan sumber daya alam untuk dapat meneruskan kehidupannya, di sisi lain keberadaan atau kelestarian Sumber Daya Alam (SDA) khususnya pesisir dan laut sangat tergantung pada aktivitas manusia sebagai pengguna (User) utama dari Sumber Daya Alam (Afriyani, 2018).

Desa pesisir merupakan entitas sosial ekonomi, sosial budaya yang menjadi batas antara daratan dan lautan. Kuatnya desa pesisir mencerminkan masyarakat di dalamnya sejahtera dan berdaya baik secara sosial ekonomi, polotik maupun ekologi. Masyarakat pesisir adalah sekumpulan masyarakat yang hidup bersama-sama mendiami wilayah pesisir membentuk dan memiliki kebudayaan yang khas, terkait dengan ketergantungan pada sumber daya pesisir. Pada sisi kesejahteraan berdasarkan hasil survey, masyarakat pesisir berada di bawah kemiskinan, yang penyebabnya dapat dibagi dalam kemiskinan struktural, kultural dan alamiah (Satria, 2009).

Pengeloaan wilayah pesisir yang merupakan salah satu upaya mengurangi kemiskinan bagi masyarakat pesisir mendapat perhatian yang sangat besar, yang diwujudkan melalui UU No. 27 Tahun 2007 tentang Pengelolaan Wilayah pesisir dan Pulau-Pulau Kecil sebagaimana telah diubah dengan undang-undang No 1 Tahun 2014. Hal ini bertujuan untuk memperbaiki mekanisme pengelolaan sumberdaya pesisir dan memperkuat kelembagaan pemerintah daerah serta masyarakat dalam mengelola sumberdaya pesisir dan pulau-pulau kecil secara seimbang dan berkelanjutan sesuai prisip-prinsip keterpaduan dan kelestarian (Satria, 2009).

Diperlukan pemberdayaan terhadap masyarakat pesisir dalam arti memberikan kekuatan kepada kelompok orang yang dianggap belum memiliki kekuatan yang diperlukan untuk kemajuan mereka dalam hal ini masyarakat pesisir yang mempunyai 
hak untuk mengelola wilayah pesisir khususnya hutan mangrove. Pemberdayaan masyarakat dalam pengelolaan hutan mengvore dapat dilakukan melalui beberapa strategi, antara lain (Afriyani, 2018): a) Strategi Persuasif. Strategi persuasif dilakukan dalam bentuk pembinaanpembinaan. Kegiatan pembinaan merupakan upaya untuk meningkatkan pemahaman dan kesadaran dari kelompok sasaran terhadap pesan yang disampaikan. Materi pembinaan meliputi penyuluhan tentang pentingnya hutan mengvore dan pelestariannya, pengelolaan tambak yang ramah lingkungan serta pentingnya organisasi/kelompok masyarakat; b) Strategi Edukatif. Strategi edukatif dilakukan dalam bentuk pelatihanpelatihan. Melalui pelatihan diharapkan dapat meningkatkan keterampilan kelompok sasaran, terhadap suatu aspek tertentu. Kegiatan pelatihan yang telah dilakukan dalam peningkatan pemahaman dan keterampilan kelompok sasaran di bidang rehabilitasi mangvore seperti seleksi buah, pembibitan dan penanaman: pelatihan peningkatkan pemahaman dan keterampilan di bidang perikanan, yaitu budidaya udang tambak ramah lingkungan dan budidaya bandeng: pelatihan pengembangan kemampuan dalam pengelolaan kelompok, seperti administrasi, pengelolaan keuangan, kepengurusan dan aturan main pelaksanaan program; c) Strategi Fasilitatif. Strategi fasilitatif dilakukan dalam bentuk pemberian bantuan usaha yang merupakan salah satu upaya dalam meningkatkan partisipasi masyarakat dalam rehabilitasi mangvore, Bantuan usaha yang diberikan umumnya berkaitan dengan program rehabilitasi mangvore, baik secara langsung maupun tidak langsung. Di samping itu bantuan juga ditujukan untuk meningkatkan kondisi sosial ekonomi kelompok sasaran.

Melalui strategi-strategi tersebut diharapkan dapat meningkatkan pemahaman dan kesadaran masyarakat terhadap keberadaan hutan mangvore yang harus dikelola untuk selanjutnya dapat dimanfaatkan guna meningkatkan perekonomian sebagaimana mestinya sehingga dapat dijaga kelestarianya antara lain melalui kegiatan pelatihan dan adanya pemberian bantuan usaha yang merupakan salah satu kelemahan masyarakat dalam berusaha yang pada umumnya adalah pengusaha kecil dan pentingnya organisasi/kelompok masyarakat dalam pengelolaan hutan mangvore .

Pengelolaan hutan mangvore diperlukan suatu kerjasama sesuai dengan sifat manusia sebagai makhluk sosial dan sekaligus makhluk ekonomi yang diwujudkan dalam bentuk kerja sama dalam kelompokkelompok, sehingga terbentuk berbagai kelompok masyarakat dalam pengelolaan mangrove tersebut.

\section{Kemitraan Usaha sebagai Wujud Pemberdayaan Kelompok Masyarakat dalam Pengelolaan Hutan Mangvore}

\section{a. Kelompok dalam Masyarakat}

Manusia adalah makhluk sosial dan sekaligus makhluk ekonomi yang terwujud melalui kerja sama dalam kelompokkelompok, sehingga dalam masyarakat dikenai berbagai kelompok masyarakat. Kelompok tersebut bertujuan untuk memperingan beban permasalahan individual dalam mencapai tujuan serta mengembangkan sikap setia kawan, kerjasama dan kebersamaan. Manfaat yang diperoleh melalui kerja sama dalam kelompok tersebut adalah mengenal antar pribadi, saling tukar informasi, adanya wadah untuk memecahkan persoalan/masalah pribadi, dapat saling memberi dan menerima, saling dapat menyelesaikan pekerjaan secara lebih efisien, untuk memperoleh perlindungan dan dukungan dari teman untuk meringankan beban dan tanggung jawab individu ("Upaya Menciptakan Kelompok Produktif Nelayan," 2017).

Terdapat beberapa prinsip dalam kerja sama dalam kelompok, yang meliputi prinsip keterbukaan, yaitu keanggotaan kelompok dapat diikuti oleh siapa saja. Prinsip keadilan dalam arti, adanya keseimbangan antara hak dan kewajiban 
bagi semua anggota. Prinsip partisipatif yaitu adanya kesempatan yang sama dalam mengelola kelompok. Kesetaraan yaitu adanya persamaan kedudukan dalam memberikan pendapat pengambilan keputusan dalam kelompok. Prinsip demokratis, dalam arti pengambilan keputusan dalam kelompok didasarkan pada kesepakatan bersama serta sukarela dimana keanggotaannya tanpa paksaan, dan adanya prinsip keberlanjutan yang berupa serta adanya jaminan dan upaya untuk mempertahankan dan mengembangkan kelompok tersebut ("Upaya Menciptakan Kelompok Produktif Nelayan,” 2017). Salah satu kelompok dalam kerja sama tersebut adalah kelompok produktif, dengan sepuluh prinsip dalam suatu kelompok produktif yang dapat tumbuh dan berkembang sesuai kebutuhan kelompok. Kelompok adalah kumpulan orang, bukan kumpulan modal. Keanggotaan terbuka dan sukarela, yang bertujuan untuk mewujudkan kesejahteraan bagi anggota, yang berprinsip dari oleh dan untuk anggota. Kelompok ini ada pertemuan yang dilakukan secara rutin dan menciptakan usaha-usaha yang produktif bagi anggota serta mengupayakan pendidikan yang terus menerus dengan administrasi tata-kelola keuangan yang bersifat terbuka. Secara umum prinsip dalam kelompok produktif adalah membangun kebersamaan masyarakat haruslah didasarkan pada sikap pandangan dan gagasan hakiki yang dijadikan pegangan untuk menghadapai, menjawab dan mengatasi segala persoalan/masalah yang menghadang. Sikap ini merupakan sikap hakiki, merupakan nilai-nilai persahabatan dan keselarasan yang dikenal dengan istilah kemitraan. Kata Mitra sendiri berarti teman, sahabat atau kawan kerja kawan senasib sepenanggungan. Demikian kemitraan merupakan suatu jalinan hubungan persahabatan atau pertemuan dalam kerjasama yang berkesinambungan ("Upaya Menciptakan Kelompok Produktif Nelayan," 2017).

Melalui program kemitraan dapat diwujudkan bilamana individu-individu yang menjalin kerjasama menumbuhkan atau mengembangkan sikap dan rasa saling terbuka, saling percaya dan saling membutuhkan. Sikap saling terbuka, saling percaya dan saling membutuhkan dalam kebersamaan di antara induvidu-induvidu tersebut akan menumbuhkembangkan suatu kelompok "homofilus" yaitu kelompok yang terdiri dari anggota-anggota yang memiliki banyak kesamaan baik dalam hal status sosial, pendidikan, mata pencaharian, profesi, minat, kesenangan, keyakinan dan sebagainya ("Upaya Menciptakan Kelompok Produktif Nelayan,” 2017).

\section{b. Kemitraan Usaha dalam Pengelolaan Hutan Mangvore}

Kelompok masyarakat merupakan gagasan rekayasa pengembangan yang menggabungkan kedua fitrah naluri manusia secara serasi, tanpa harus mempertentangkannya. Kedua fitrah naluri tersebut adalah fitrah manusia sebagai makhluk sosial dan makhluk ekonomi.

Manusia adalah makhluk sosial yang tidak dapat hidup sendiri. Sejak lahir manusia membutuhkan kasih sayang, persaudaraan dan kerjasama dengan orang lain untuk dapat berkembang, namun di sisi lain setiap orang ingin kebutuhan ekonominya terpenuhi. Manusia mengejar kepuasan dan kemakmuran bagi dirinya sendiri.

Naluri untuk memperoleh keuntungan sebesar-besarnya juga menjadi fitrah manusia yang normal. Secara utuh manusia memang harus diterima dalam fitrahnya sebagai insan sosial yang haus kasih sayang dan persaudaraan, sekaligus juga mahluk ekonomi yang mengejar keuntungan bagi dirinya sendiri.

Fitrah manusia tersebut tentunya juga ada pada masyarakat yang hidup di daerah pesisir, khususnya yang mengelola hutan mangrove. Sebagai makhluk sosial dan makhluk ekonomi, tentunya butuh kerjasama untuk memperoleh keuntungan yang sebesar-besarnya. Kemitraan merupakan salah satu wujud kerja sama tersebut. 
Pengelolaan hutan mangvore dapat dikategorikan sebagai bagian dalam bidang perekonomian yang banyak memperoleh keuntungan. Kemitraan pun diyakini sebagai salah satu upaya untuk menggerakan potensi ekonomi, karena kemitraan merupakan hubungan antar pihak pelaku ekonomi yang didasarkan pada ikatan usaha yang saling menguntungkan, dan hubungan kerja yang sinergis. Kemitraan menjadi hubungan kerjasama yang mengedepankan prinsip saling menunjang, saling mendukung, saling menghidupi berdasarkan azas kekeluargaan, kebersamaan dan saling menguntungkan, yang dapat memberdayakan masyarakat yaitu memberikan kekuatan kepada kelompok dalam hal ini masyarakat pesisir pengelola hutan mangrove yang belum memiliki kekuatan yang diperlukan untuk kemajuan.

Pemerintah Indonesia telah memberlakukan kemitraan usaha dalam pengembangan usaha kecil sebagaimana diatur dalam Peraturan Pemerintah No. 44 Tahun 1997 tentang Kemitraan. Untuk mewujudkan suatu kemitraan usaha yang kokoh perlu ditetapkan ketentuan mengenai tata cara penyelenggaraan, pembinaan, dan pengembangannya. Sehubungan dengan hal tersebut dikeluarkanlah Peraturan Pemerintah No. 44 tentang Kemitraan, yang mengatur lebih lanjut tentang pola kemitraan usaha yang telah diatur dalam UndangUndang tentang Usaha Kecil, yang meliputi iklim usaha, dan pembinaan dan pengembangan, pembiayaan, dan penjaminan serta kemitraan.

PP No. 44 Tahun 1997 tentang kemitraan ini, telah dicabut dan dinyatakan tidak berlaku dengan PP No 17 tahun 2013 sebagaimana diatur dalam ketentuan Pasal 62 huruf b, yaitu pada saat peraturan pemerintah ini berlaku, PP No. 44 Tahun 1997 tentang kemitraan (Lembaran Negara RI 1997 No. 91), tambahan lembaran NRI No. 3718 dicabut dan dinyatakan tidak berlaku.

PP No.17 Tahun 2013 ini merupakan pelaksanaan Undang-Undang Nomor 20 Tahun 2008 tentang Usaha Mikro, Kecil,
Dan Menengah sebagaimana diatur dalam ketentuan Pasal 37 yang mengatur ketentuan lebih lanjut mengenai pola kemitraan sebagaimana dimaksud dalam Pasal 26 yang diatur dengan Peraturan Pemerintah, sedangkan Undang-Undang Nomor 20 Tahun 2008 tentang Usaha Mikro, Kecil, dan Menengah, menggantikan UU No. 9 Tahun 1995 tentang Usaha Kecil sebagaimana diatur dalam Pasal 42 UndangUndang Nomor 20 Tahun 2008 tentang Usaha Mikro, Kecil, dan Menengah.

Menurut UU No 20 Tahun 2008 dan PP No.17 Tahun 2013, Kemitraan diberi pengertian sebagai kerjasama dalam keterkaitan usaha, baik langsung maupun tidak langsung, atas dasar prinsip saling memerlukan, mempercayai, memperkuat, dan menguntungkan yang melibatkan pelaku Usaha Mikro, Kecil, dan Menengah dengan Usaha Besar.

Menurut ketentuan Pasal 25 (1) Undang-Undang Nomor 20 Tahun 2008 Tentang Usaha Mikro, Kecil, Dan Menengah , Pemerintah, Pemerintah Daerah, Dunia Usaha, dan masyarakat memfasilitasi, mendukung, dan menstimulasi kegiatan kemitraan, yang saling membutuhkan, mempercayai, memperkuat, dan menguntungkan, sedangkan ketentuan ayat (2) nya mengatur bahwa Kemitraan antar-Usaha Mikro, Kecil, dan Menengah dan Kemitraan antara Usaha Mikro, Kecil, dan Menengah dengan Usaha Besar mencakup proses alih keterampilan di bidang produksi dan pengolahan, pemasaran, permodalan, sumber daya manusia, dan teknologi.

Pasal 10 PP No.17 Tahun 2013 tentang Pelaksanaan Undang-Undang Nomor 20 Tahun 2008 tentang Usaha Mikro, Kecil, Dan Menengah, mengatur tentang pelaksanaan kemitran yang harus memperhatikan prinsip Kemitraan dan menjunjung etika bisnis yang sehat. Prinsip Kemitraan sebagaimana tersebut meliputi prinsip saling membutuhkan, saling mempercayai, saling memperkuat dan saling menguntungkan. Dalam pelaksanaan kemitraan ini para pihak mempunyai 
kedudukan hukum yang setara dan terhadap mereka berlaku hukum Indonesia, dan dilaksanakan dengan disertai bantuan dan perkuatan oleh Usaha Besar.

Kemitraan tersebut menurut ketentuan Pasal 26 UU Undang-Undang Nomor 20 Tahun 2008 tentang Usaha Mikro, Kecil, dan Menengah dan PP No. 17 Tahun 2013 dilaksanakan dengan pola inti-plasma, subkontrak, waralaba, perdagangan umum, distribusi dan keagenan; serta bentuk-bentuk kemitraan lain, seperti: bagi hasil, kerjasama operasional, usaha patungan (joint venture), dan penyumberluaran (outsourcing).

Pelaksanaan kemitraan tersebut mencakup proses alih keterampilan bidang produksi dan pengolahan, pemasaran, permodalan, sumber daya manusia, dan teknologi sesuai dengan pola Kemitraan. Dalam pelaksanaan kemitraan ini Usaha Besar dilarang memiliki dan/atau menguasai Usaha Mikro, Usaha Kecil, dan/atau Usaha Menengah mitra usahanya demikian juga dengan Usaha Menengah (Pasal 11 dan 12 PP No.17 Tahun 2013 tentang Pelaksanaan Undang-Undang Nomor 20 Tahun 2008 tentang Usaha Mikro, Kecil, dan Menengah).

Hubungan hukum para pihak dalam kemitraan usaha tersebut berdasarkan suatu perjanjian yang dibuat secara tertulis sebagaimana diatur dalam ketentuan Pasal 29 PP No.17 Tahun 2013 tentang Pelaksanaan Undang-Undang Nomor 20 Tahun 2008 Tentang Usaha Mikro, Kecil, Dan Menengah. Setiap bentuk Kemitraan yang dilakukan oleh Usaha Mikro, Usaha Kecil, dan Usaha Menengah dituangkan dalam perjanjian Kemitraan yang dibuat secara tertulis dalam Bahasa Indonesia. Jika salah satu pihak dalam perjanjian kemitraan tersebut adalah orang atau badan hukum asing, maka perjanjian Kemitraan harus dibuat dalam Bahasa Indonesia dan bahasa asing. Isi perjanjian kemitraan tersebut paling sedikit memuat kegiatan usaha, hak dan kewajiban masing-masing pihak, bentuk pengembangan dan jangka waktu serta penyelesaian perselisihan.
Sumber hukum perjanjian di Indonesia diatur dalam buku III Kitab Undang Undang Hukum Perdata (KUH Perdata). KUH Perdata terdiri dari 4 buku, yaitu: Buku I tentang Orang, Buku II tentang Benda, Buku III tentang Perikatan, Buku IV tentang Pembuktian dan Daluwarsa.

Perjanjian merupakan salah satu sumber perikatan. Perikatan adalah hubungan hukum antara dua orang atau dua pihak dimana pihak yang satu berhak menuntut sesuatu hal dari pihak lain, dan pihak lain berkewajiban untuk memenuhi tuntutan itu. Pihak yang menuntut sesuatu disebut Kreditur, sedangkan pihak yang berkewajiban memenuhi tuntutan disebut Debitur. Hubungan antara dua orang atau dua pihak tersebut merupakan hubungan hukum yang menimbulkan akibat hukum yang dijamin oleh hukum atau undangundang. Apabila salah satu pihak tidak memenuhi hak, dan kewajiban secara sukarela, maka salah satu pihak dapat menuntut melalui pengadilan.

Buku III KUH Perdata yang mengatur tentang perikatan terdiri dari $18 \mathrm{Bab}$ (titel) ditambah dengan titel VII A dengan sistematika sebagai berikut, Bab I terdiri dari Pasal 1233 s/d 1312 tentang perikatan pada umumnya. Bab II terdiri dari Pasal 1313 s/d 1351 mengatur tentang perikatanperikatan yang timbul dari perjanjian. Bab III terdiri dari Pasal 1352 s/d 1380 mengatur tentang perikatan-perikatan yang timbul karena undang-undang. Bab IV terdiri dari Pasal 1381 s/d 1456 mengatur tentang hapusnya perikatan-perikatan. Bab $\mathrm{V}$ s/d Bab XVIII ditambah Bab VII A terdiri dari Pasal 1457 s/d 1864 mengatur tentang perjanjian perjanjian khusus.

Bab I s/d Bab IV dari Buku III tersebut mengatur tentang ketentuan umum, sedangkan Bab V s/d XVIII ditambah VII A mengatur tentang ketentuan-ketentuan khusus yang mengatur perjanjian khusus atau perjanjian bernama, yaitu: perjanjian jual-beli, perjanjian tukar-menukar, perjanjian sewa-menyewa, perjanjian hibah, perjanjian persekutuan, perjanjian penitipan barang, perjanjian pinjam-pakai, perjanjian 
untuk melakukan pekerjaan, perjanjian pinjam-meminjam, bunga tetap atau bunga abadi, perjanjian untung-untungan, perjanjian pemberian kuasa, perjanjian penanggungan, perjanjian perdamaian.

Di dalam masyarakat dalam rangka memenuhi kebutuhan, muncul perjanjianperjanjian baru yang tidak diatur dalam KUH Perdata, sebagaimana perjanjianperjanjian tersebut di atas. Satu di antaranya adalah perjanjian kemitraan usaha. Hal ini dimungkinkan karena Buku III KUH Perdata bersifat terbuka dengan asas kebebasan berkontraknya sebagaimana diatur dalam Pasal 1338 ayat 1, yaitu adanya kebebasan yang diberikan kepada masyarakat untuk mengadakan perjanjian yang berisi dan, macam apapun, asalkan tidak bertentangan dengan peraturan perundang-undangan, kesusilaan, dan ketertiban umum.

Pasal 1338 KUH Perdata juga mengatur tentang asas kekuatan mengikat Perjanjian yaitu perjanjian yang dibuat secara sah mengikat sebagai undang-undang bagi para pihak yang membuatnya. Syarat sahnya perjanjian diatur dalam Pasal $1320 \mathrm{KUH}$ Perdata, yang dibedakan dalam syarat subyektif dan syarat obyektif. Syarat subyektif meliputi sepakat dan cakap, jika tidak dipenuhi perjanjian dapat dibatalkan, sedangkan syarat obyektif meliputi hal tertentu dan sebab yang halal jika tidak terpenuhi perjanjiannya batal demi hukum.

Perjanjian menurut C. Asser sebagaimana dikutip Herlien Budiono adalah salah satu perbuatan/tindakan hukum yang terbentuk dengan tercapainya kata sepakat yang merupakan pernyataan kehendak bebas dari dua orang (pihak) atau lebih, dimana tercapainya sepakat tersebut tergantung dari para pihak yang menimbulkan akibat hukum untuk kepentingan pihak yang satu dan atas beban pihak yang lain atau timbal balik dengan mengindahkan ketentuan perundangundangan (Budiono, 2010).

Berdasarkan ketentuan yang diatur dalam PP No. 17 Tahun 2013 tentang Pelaksanaan Undang-Undang Nomor 20
Tahun 2008 tentang Usaha Mikro, Kecil, dan Menengah, serta KUH Perdata, kerjasama kemitraan mangrove yang merupakan strategi pemberdayaan dalam pengeloaan hutan mangrove harus dituangkan dalam perjanjian, yang memenuhi ketentuan Pasal 1320, yang antara lain berisi hak dan kewajiban para pihak sesuai dengan pola kemitraan yang digunakan. Pemilihan pola kemitraan yang digunakan ini disesuaikan dengan kebutuhan yang diperlukan oleh masyarakat pesisir pengelola hutan mangrove.

\section{Simpulan}

Strategi yang dapat dilakukan dalam pemberdayaan masyarakat untuk pengelolaan konservasi hutan mangrove terdiri dari strategi persuasif, strategi edukatif dan strategi fasilitatif, dalam suatu kemitraan usaha. Terdapat berbagai pola kemitraan yang diatur dalam UndangUndang Nomor 20 Tahun 2008 tentang Usaha Mikro, Kecil, dan Menengah yang diatur lebih lanjut dalam PP No.17 tentang Pelaksanaan Undang-Undang Nomor 20 Tahun 2008 tentang Usaha Mikro, Kecil, dan Menengah yang dapat digunakan dalam pemberdayaan masyarakat pesisir pengelola hutan mangrove. Pemilihan pola kemitraan yang akan digunakan, disesuaikan dengan kebutuhan.

\section{DAFTAR PUSTAKA}

Afriyani, A. Y. (2018). Pengelolaan Ekosistem Mangrove Melalui Pemberdayaan Masyarakat Pesisir. Tegal: Widyasiwara BPPP.

Bonorowo. (2015). Persepsi, sikap, dan partisipasi masyarakat dalam pengelolaan hutan mangrove di Wonorejo, Surabaya Jawa Timur.

Budiono, H. (2010). Ajaran Umum Hukum Perjanjian dan Penerapannya di Bidang Kenotariatan. Bandung: Citra Aditya Bakti.

Mahmudah, S. (2008). Tinjauan Yuridis Terhadap Kerja Sama Pola Subkontrak 
Pada Industri Kecil (Studi Kasus Pada Industri Logam). Universitas Diponegoro.

Huda, N. (2008) Strategi Kebijakan Pengelolaan Mangrove Berkelanjutan Di Wilayah Pesisir Kabupaten Tanjung Jabung Timur Jambi. Universitas Diponegoro.

Mulyadi, E., Hendriyanto, O., \& Fitriani, N. (2010). Konservasi hutan mangrove sebagai ekowisata. Jurnal Ilmiah Teknik Lingkungan, Vol. 2 (No. 1), pp 51-57.

Pramudi. (2001). Ekosistem Hutan Mangrove dan Peranannya sebagai Habitat berbagai fauna Aquatik. 'Oseana, XX VI(4), 14. Retrieved from www.oseanografi.lipi.go.id
Satria, A. (2009). Pesisir dan Laut untuk Rakyat. Bogor: IPB Press.

Soedarsono, T. (2004). Wacana Penegakan Hukum dan Pengelolaan Sumberdaya Alam dalam Perspektif Otonomi Daerah. Denpasar: Ratna Sari.

Umiha, E., \& Asbar. (2006). Formulation of Mangrove ecosystem management model based on eco-minawisata in the Coastal Sinjai, South Sulawesi. In Procedia - Sosial and Behavioral Science (pp. 704-711).

Upaya Menciptakan Kelompok Produktif Nelayan. (2017). Retrieved from http://perikanan38.blogspot.com/2014/0 8/upaya-menciptakan-kelompokproduktif.html 